\title{
BUPRESTIS GIGANTEA.
}

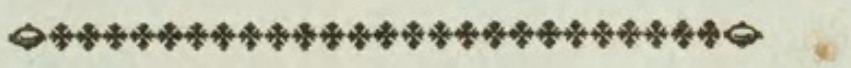

Character Genericus.

Antenne filiformes, ferratæ, longitudine thoracis. Palpi quatuor, filiformes; articulo ultimo obtufo truncato.

Caput dimidium intra thoracem retractum.

Lin. Syf. Nat. Gmel. p. 1926.

\section{CHARACTER SPECIFICUS.}

BUPRESTIS elytris faftigiatis, bidentatis, rugofis, thorace marginato lævi, corpore inaurato.

$$
\text { Lin. Syf. Nat. p. } 659 .
$$

CERAMBYX INDIÆ orientalis maximus.

$$
\text { Grew. mus. } 165 \text {. t. } 13 .
$$

CANTHARIS maxima elytris cuprei coloris fulcatis.

Sloan. jam. 2. p. 210. t. 236. f. 1. 2. BUPRESTIS GIGANTEA.

$$
\text { Degeer. inf. 4. p. 134. n. } 1 .
$$

Bupreftidis generi peculiaris eft quidam et quafi metallicus fplendor, qui in nonnullis fpciebus, exoticis 
ticis præcipue, adeo dominatur, ut aurum cuprumve fumma arte politum æmuletur. Tinguntur quædam fpecies colore aureo-viridi, cui cedit longe quicquid pigmenti eft aut vernicis. Illam de qua jam agitur vincunt multæ fulgido colore, nullæ magnitudine; cumque larvam ejus notaverit et eleganter depinxerit Domina Merian, vifum eft ut melius explicetur genus, illam ipfam una cum infecto infpiciendam offerre. Larva ad magnitudinem qua depingitur crefcere, et prope radices plantarum degere folet. Plene aucta dormit ad tempus cava fub humo, cuteque exteriore exuta, in pupam feu chryfalidem mutatur, e qua, elapfo quodam fpatio, emergit infectum perfectum; cujus color generalis eft quafi cupri politi, thoracis elytrorumque marginibus plus minus viridi tinctis. Elytrorum fuperficies eft paulum fcabrofa et rugofa, ftriis aliquot in longitudinem ductis quafi coftata.

Notandum eft antennas Bupreftidis giganteæ non mere fetaceas esse, ut plerisque ejufdem generis, fed lamellis paululum pectinari. Americam Auftralem incolit pulcherrimum hoc infectum. 



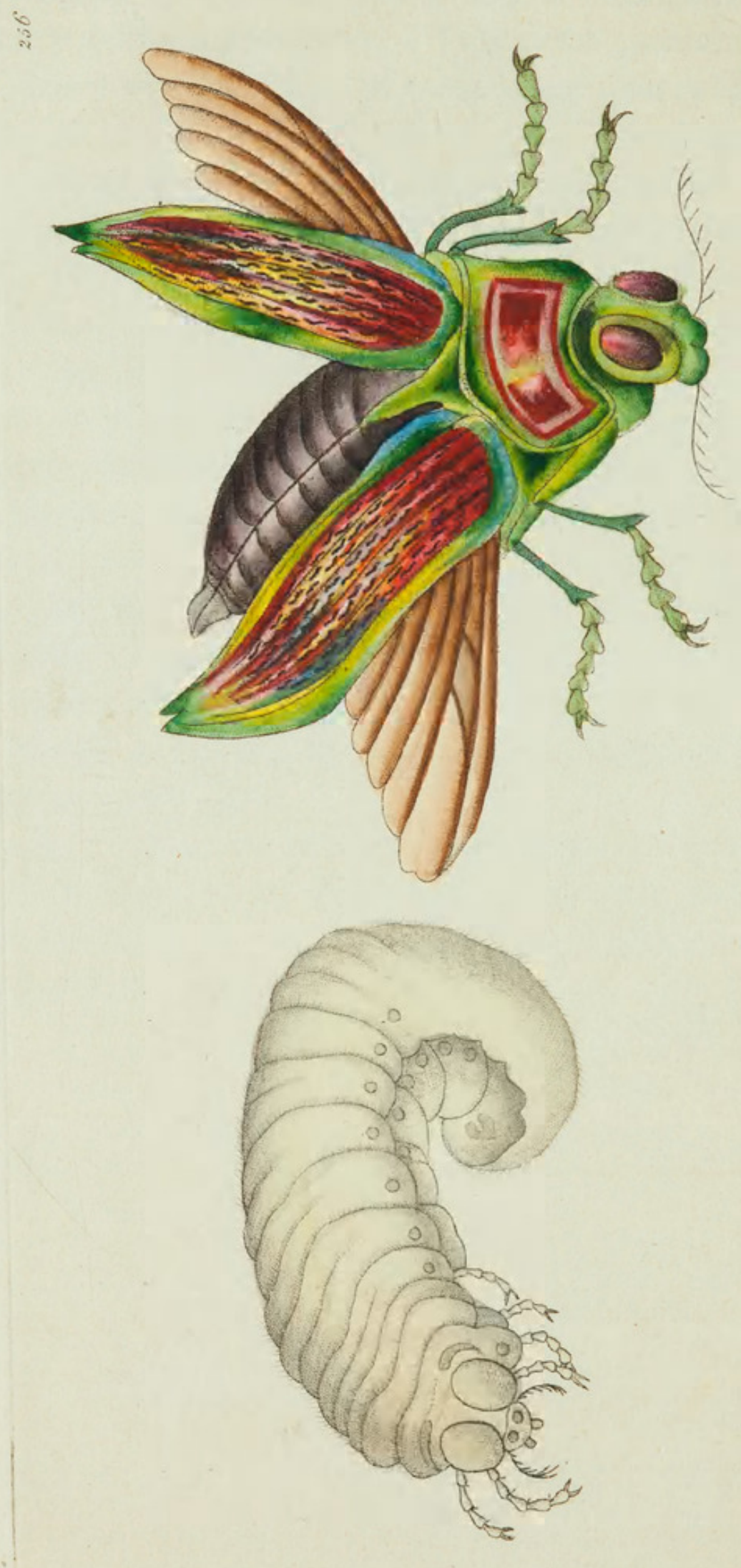




\section{GREAT BUPRESTIS.}

\section{Q}

\section{GENERIC CHARACTER.}

Antenna filiform, and fometimes ferrated; of the length of thorax.

Feelers or Palpi filiform: with the laft joint obtufe or truncated.

Head partly retracted under the thorax.

\section{SPECIFIC CHARACTER.}

COPPER-COLOURED BUPRESTIS with a glofs of green-gold; the wing-rhells wrinkled, and bidentated at the extremities. The GREAT COPPER-COLOURED BU. PRESTIS.

The GREAT GOGGLE-EYED BEETLE.

Grew's Mufeum Reg. Soc.

Merian Sur. pl. 50.

The genus Bupreftis is remarkable for the metallic fplendor by which moft of the exotic fpecies are diftinguifhed; and which in fome is fo great as to equal the appearance of the moft highly-polifhed 
gold or copper: others are ornamented with a tinge of golden green, which far exceeds the appearance of all artificial painting or varnifh. The prefent fpecies, though lefs rich in colour than feveral others, is the largeft of the whole genus; and as its larva has been obferved and well figured by Madam Merian, I have thought it not improper, as an elucidation of the genus, to add the larva as reprefented by that lady, to the figure of the compleat infect. This larva grows to the fize reprefented, and refides near the roots of plants: when fully grown, it lies dormant for fome time in a fmall cavity beneath the furface of the ground, and, cafting its exterior fkin, becomes a pupa or chryfalis, out of which, after a certain fpace, proceeds the perfect infect. Its general colour is that of highlypolifhed copper; the edges of the thorax and wingcafes tinged more or lefs with green. The wingcafes are of a roughifh or wrinkled furface, and nightly ribbed longitudinally. It is to be alfo obferved that the antennæ, which in moft of the genus are fimply fetaceous, are in the prefent fpecies of a fomewhat lamellated or pectinated appearance. This beautiful infect is a native of South America. 


\section{$2 \mathrm{BHL}$ Biodiversity Heritage Library}

Shaw, George. 1796. "The Great Burprestis, Buprestis gigantea [PI. 256]." The Naturalist's Miscellany 8(LXXXVI), https://doi.org/10.5962/p.310799.

View This Item Online: https://www.biodiversitylibrary.org/item/276320

DOI: https://doi.org/10.5962/p.310799

Permalink: https://www.biodiversitylibrary.org/partpdf/310799

\section{Holding Institution}

Museums Victoria

\section{Sponsored by}

Atlas of Living Australia

\section{Copyright \& Reuse}

Copyright Status: Public domain. The BHL considers that this work is no longer under copyright protection.

This document was created from content at the Biodiversity Heritage Library, the world's largest open access digital library for biodiversity literature and archives. Visit BHL at https://www.biodiversitylibrary.org. 